\title{
Independent National Electoral Commission and Campaign Financing Monitoring in Nigeria: The 2015 General Elections
}

\author{
${ }^{1}$ Babayo Sule, ${ }^{2}$ Mohd Azizuddin Mohd Sani \& ${ }^{2}$ Bakri Mat \\ ${ }^{I}$ Department of Political Science, Faculty of Humanities Management and Social \\ Sciences, Federal University Kashere Gombe Gombe State Nigeria \\ ${ }^{2}$ School of International Studies, College of Law Government and International Studies, \\ Universiti Utara Malaysia, Malaysia \\ babayosule@gmail.com; azizuddin@uum.edu.my; bakri@uum.edu.my \\ DOI: https://doi.org/10.32890/jis2017.13.2
}

\begin{abstract}
The Independent National Electoral Commission (INEC) is the electoral umpire responsible for the conduct of general elections in Nigeria and other related electoral activities since the resurgence of democratic rule in 1999. One of these important electoral activities carried out by INEC is campaign monitoring and political party financing activities as provided in the Nigerian Constitution and the 2010 Electoral Act. This paper examined the role of INEC in monitoring candidates and parties' expenditure during the 2015 General Elections. The major problem was the way parties and candidates violated the regulations while INEC as the monitoring body was watchful without any concrete action. The paper used the qualitative method of data collection and analysis where the researchers went to the field and consulted informants in the affected agencies and individuals through interviews and Focus Group Discussions. The data obtained from the field was analysed using tables and other techniques of qualitative data analysis. The paper concludes that, politicians and their political parties spent above the campaign spending limits as provided by law in the 2015 General Elections and the electoral body (INEC) did not monitor properly the campaign spending due to lack of political will from policy-makers and loopholes in the law that empowered them to monitor the spending. The research recommends that for proper and effective campaign financing monitoring in future elections, INEC should be mandated to monitor all politicians and their activities during and after elections, the anti-graft agency (EFCC) should be involved in screening candidates while the Code of Conduct Bureau should be reinforced in watching public servants' assets.
\end{abstract}

Keywords: INEC, political party, election, campaign, political financing, regulations.

\section{Introduction}

The Independent National Electoral Commission (INEC) is the body responsible for the conduct of general elections in Nigeria's Fourth Republic (from 1999 to date). It was 
established by the provisions of the 1999 Constitution as amended and it has successfully conducted five consecutive successful general elections. INEC has constitutional powers and the Electoral Act 2010 mandates the Commission to undertake responsibilities of conducting elections and registration as well as monitoring political parties and their activities. Political party financing is a difficult task to monitor and regulate even in advanced democracies as a result of the allegations of corrupt practices involved and the absence of a strong legal mechanism for the monitoring. The Department that is responsible for monitoring and auditing political parties during general elections was introduced in 2010 and it has been in operation for the two previous elections in 2011 and 2015. This is a research work is on the role and effectiveness or otherwise of INEC in monitoring political parties' campaign expenditure during the 2015 General Elections.

There are well-provided rules and regulations in the Constitution and the 2010 Electoral Act which clearly articulate the legal means and procedures for party funding including its maximum spending limit, auditing and other related issues. INEC is empowered constitutionally to regulate such expenditure and monitor party activities during elections. However, despite its constitutional powers, INEC could not monitor effectively and regulate political party financing during the 2015 General Elections as a result of the lack of political willingness and the dubious nature of politicians' manipulation of the process. This led to excessive campaign spending, which was unprecedented in the history of Nigeria's elections, by the two major political parties; All Progressive Congress (APC) and Peoples Democratic Party (PDP), above the set spending limit. While there are some studies on this subject matter, little or no attention is given to the specific role of INEC in campaign financing monitoring. The existing works emphasized mostly on political party financing by godfathers and the corruption in the process. This is the area of research contribution that this paper fulfills.

The major objectives of the paper are categorised into two: (a) to examine the provisions on regulations in political party financing in Nigeria during the 2015 General Elections and the powers of INEC in monitoring the financing and (b) to analyse whether INEC was able to monitor the campaign spending as empowered by the Constitution and the extent of the monitoring or its success.

\section{Methodology And Analysis}

The paper used the qualitative method of data collection and analysis. Qualitative data analysis is a paradigm of research work which involves the use of meanings and words for data collection and their interpretation. It is used in both primary and secondary sources for research in a qualitative way suitable for the research in question and the environment of the research. Qualitative research is not about data and techniques only. It is also about the application of qualitative strategies for qualitative paradigms. It involves the utilisation of the spoken and written words, understanding and interpretating meanings, generating a narrow rich data and the exploration of deeper analysis within a given context of meanings. ${ }^{15}$ 
This research was a case study of the qualitative method type where the 2015 General Elections were taken as the specific case of analysis. It was an evaluation and an in-depth analysis of a specific event that took place within a specific period and time and it was a particular case study because it focused on a particular event or a phenomenon which was the 2015 General Elections.

The research used primary and secondary sources of data. The primary source was in-depth personal interviews with selected informants. Some informants were selected from certain categories including politicians, party stakeholders, INEC senior officials, academicians and electorates. For the politicians' part, some serving elected officers and contestants at both the national and local levels were interviewed. National party executives of four selected major parties were interviewed including APC, DPP, PDP and SDP. Some INEC senior national officials were interviewed while academic experts in the area of study were consulted for the interview and interviewers were selected in Abuja from members of the Civil Society Situation Room who helped in the monitoring of elections during the 2015 General Elections.

The research also used documented primary sources such as reports from governmental publications and international organisations and agencies including the Central Bank of Nigeria (CBN), the United States Agency for International Development (USAID) and the United Kingdom Agency for International Development (UKAID), the International Republican Institute (IRI), the Centre for Public Policy Alternative (CPPA), the Nigerian 1999 Constitution, the Electoral Act 2010 and other documents. In addition, the research used secondary sources which consisted of the existing literature in the area of study from books, journals, articles and Internet sources.

The data obtained from the field was analysed through the use of themes that were interpreted from the words of the informants in relation to the existing knowledge in the field for analysis. The results arrived at were discussed and interpreted for findings and future recommendations.

\section{Literature Review}

In this section, an attempt was made to examine the various scholastic views and other related documents on the subject matter of the study for critical reviews and identification of the area of contribution of the paper to knowledge. This section is divided into sub-sections under themes for analytical purpose.

\section{The Independent National Electoral Commission}

The Independent National Electoral Commission (INEC) is the national electoral body in Nigeria which is responsible for the overall supervision and conduct of general elections in 
the country including other related procedures such as registration of voters, delineation of constituencies, setting dates for conducting for elections, registration and de-registration of political parties as well as supervision and monitoring of political parties and regulations of campaign activities and elections. It was established in 1999 with the resurgence of democratic rule in Nigeria after more than a decade of military rule. As a result of the failure of the previous electoral umpires, INEC was in the beginning established to be independent and transparent according to the Constitutional clause that established the Commission.

\section{The Establishment of the Independent National Electoral Commission}

The Independent National Electoral Commission (INEC) was established by the Nigerian military in 1998 under Decree No 17 of 1998. On $5^{\text {th }}$ August 1998, the Commission was passed into law where it was stated that:

"The Federal Military Government hereby decrees as follows: There should be a body known as the Independent National Electoral Commission to be referred to according to this Decree as the "Commission." The Commission shall be a body that is corporate with perpetual succession, and may sue and be sued in its corporate name".

The Decree later became famously known as the Independent National Electoral Commission Establishment Decree 1998.

The origin of electoral commissions in Nigeria started from the colonial period when the Electoral Commission of Nigeria (ECN) was established to conduct the 19

59 General Elections that led to the ushering of political independence. The entire First Republic (1960-1966) elections were conducted by ECN. The ECN was dissolved after the first military coup in 1966. In 1978, a new electoral commission was established named the Federal Electoral Commission (FEDECO) by the military regime to conduct the 1979 General Elections. The FEDECO remained the electoral umpire in the country until after the military coup of 1983 which ended the Second Republic (1979-1983) in Nigeria and introduced another military rule for many decades (INEC, 2017).

In 1990, the Military Regime of General Ibrahim Babangida established the National Electoral Commission (NEC) which conducted the controversial June 12, 1991 Presidential Election that was annulled by the same Military Regime leading to the emergence of what was called the "Aborted Third Republic" in Nigerian political history. The Military Regime of General Sani Abacha dissolved NEC and established the National Electoral Commission (NECON) in an attempt for another civilian rule that failed before the actualisation as a result of the eventual death of General Sani Abacha.

In 1998, General Abdulsalami Abubakar's Military Administration dissolved NECON and introduced the decree that led to the establishment of INEC as the current electoral body 
in the Fourth Republic (1999-date). On realizing the state's domination and control of the electoral umpire and politicization of the body, the decree sought to make the Commission independent in structure and in terms of financing as the name implied. However, INEC was far from being independent in terms of the conduct of elections particularly the 2003 and 2007 General Elections which were bedeviled with huge outcries of rigging and irregularities at both the local and international levels. The reasons behind such a negative phenomenon are explained in later sections.

\section{Powers and Functions of the Independent National Electoral Commission}

Section 225 Sub-sections 1-6 and Section 226 Sub-sections 1-3 of the Nigerian 1999 Constitution empower INEC to monitor and supervise all electoral and financial activities of political parties and their members according to its periodic discretion. In addition, Section 88 and its Sub-sections of the 2010 Electoral Act empower INEC to monitor and sanction parties financially in terms of its income and expenditure. Section 91 Sub-sections 1-7 empower INEC to set limits to maximum campaign spending for various elective offices at the federal, state and local levels and Section 92 Subsections 1-7 provide for INEC to sanction any party or person that violates the provisions of Section 91. Other Sections in the Electoral Act 2010 empower INEC to monitor and regulate all activities and finances of political parties and candidates that contest for any elective office. Thus, the above legal provisions bestowed much power on INEC over political parties and contestants but the problem was whether such powers were efficiently utilized or not.

INEC was expected, according to the decree that established it, to perform the following functions:

1. Organise, conduct and supervise all elections and matters pertaining to elections to, all the elective offices provided in the Constitution of the Federal Republic of Nigeria 1999 as amended or any other enactment or law;

2. Register political parties in accordance with the provision of the relevant enactment or law;

3. Monitor the organisation and operation of the political parties including their finances;

4. Arrange for the annual examination of and auditing of the funds and accounts of the political parties and publish reports on such examination and audit for public information;

5. Conduct the registration of persons qualified to vote and the preparation, maintenance and revision of the register of voters for the purpose of any election;

6. Monitor political campaigns and provide rules and regulations which shall govern the political parties;

7. Ensure that all Electoral Commissioners, Electoral and Returning Officers take and subscribe to the oath of office prescribed by law;

8. Delegate any of its powers to any State Resident Electoral Commissioner and carry out such other functions as may be conferred upon it by a decree or any other enactment or law. 
The above functions have been undertaken by INEC since 1999 although some might not have taken place or were dismal in terms of implementation. One can simply conclude in this section that if the rules are fully operated and INEC is really independent, it has all the powers to sanction a fair and credible election in Nigeria, but why is it that always the elections are followed with lamentations of lack of credibility and series of litigation? Further examination in the other sections of this paper will reveal why.

\section{Organisational Structure of INEC}

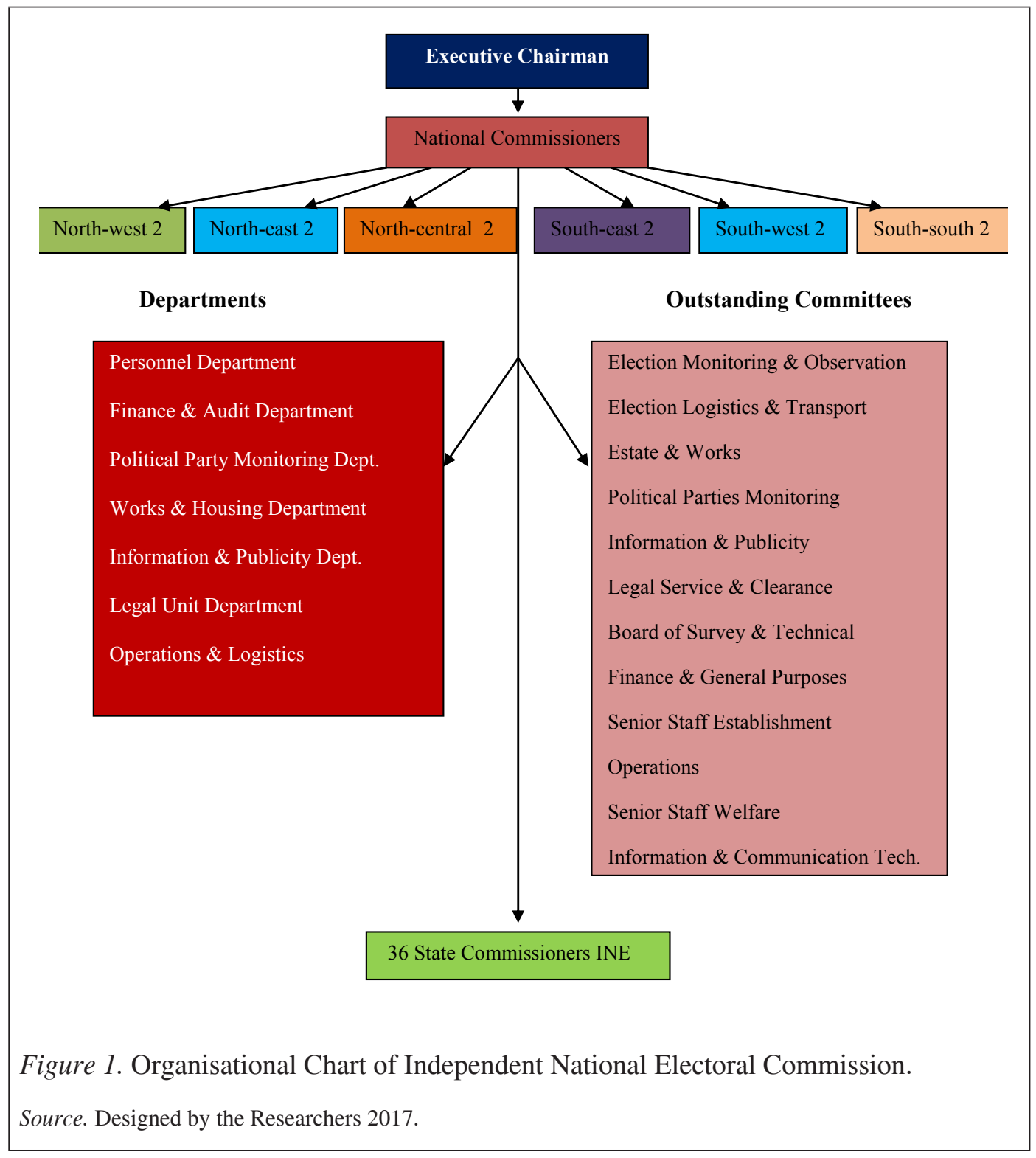


The Independent National Electoral Commission is headed by the Executive Chairman who is appointed by the President of the Federal Republic of Nigeria after approval by the National Assembly. There are 12 National Commissioners with 2 drawn from each of the six geo-political zones (North-west, North-east, North-central, South-west, Southeast and South-south). The Commission comprises of seven (7) departments and thirteen (13) outstanding committees and state offices in the 36 states headed by a coordinator. The above explanation is presented in a chart for clarity of expression and conveniency of understanding.

\section{Independent National Electoral Commission and the Challenges of Election Conduct in Nigeria}

INEC as the national electoral body has conducted five consecutive general elections, more than any other electoral body in the history of the country. The elections that were conducted by INEC took place in 1999, 2003, 20072011 and 2015, and that of 2019 fast approaching. In the process of the conduct of elections, INEC usually prepares ahead, designes the electoral budget and submits it to the Presidency which in return presents it to the National Assembly for scrutiny and questions as well as approval. For instance, the 2015 General Elections was seen as the most expensive in the history of Africa with a whopping sum of N125 billion ( $\$ 340,863,696.382$ million) approved by the government for the INEC to conduct the elections and that amount has never been spent in the history of elections in Africa.

After the conduct of the 2007 General Elections, many analysts concluded that the elections that were conducted by the military during the transition to democratic rule were far better organised and credible than that of the INEC under civilian rule. Why? This was because of the intricacies of the processes and performances as well as the outcome of the elections which left much to be desired. For instance, the Human Rights Watch reported in 2007 that the 2003 and 2007 General Elections were not far from being broad daylight robbery and the mockery of elections and democracy. The report further argued that there was vote buying, ballot stealing, ballot stuffing, intimidation of voters, violence, massive riggings and alteration of results openly in the electoral process. The Observer Book of Scandal (2010) also attested to the above position where it cited that the 2007 General Elections in Nigeria was the third most controversial election in the history of this world according to their records.

Even though in some instances INEC was found to be a complementary factor in the irregularities and malpractices that took place in the electoral process in Nigeria, the entire process was hijacked and subverted by the politicians who overpowered all efforts put in by INEC in making the elections presentable and credible as well as acceptable. Politicians turned politics into war and strove to win at all costs using all forms of manipulative activities such as vote buying, excessive spending above the set limit, hiring thugs, rigging and other forms of corrupt practices in the electoral process. In the real sense of it, while 
there might be dubious and corrupt behaviour from the INEC in the conduct of general elections in Nigeria, the activities and attitudes of politicians made it extremely difficult for INEC to have the freedom of conducting a credible and acceptable election at the national and international levels.

However, fortunately, in the 2015 General Elections, INEC under the leadership of a reputable Professor of Political Science, Attahiru Mohammed Jega, succeeded in conducting an election that was seen as credible and fair, unprecedented in the history of the Nigerian Fourth Republic. Perhaps, some of the factors that contributed to the success of INEC in conducting a credible election in 2015 were the introduction of card readers for electronic voting which drastically curbed rigging and other irregularities in addition to the emergence of a strong opposition party, APC which squarely challenged PDP in the polls. Other issues that contributed to the success of the elections included the insecurity issue, corruption, poverty, unemployment and the desire of Nigerians to do away with the sixteen (16) wasteful years of PDP rule.

\section{The 2015 General Elections}

The 2015 General Elections is still judged as the most credible in the Fourth Republic or at least one of the most fair and credible in the history of Nigeria. This is the result of the new trend that emerged from the elections and the entire process of conducting the elections in general. Apart from the use of smart card readers and the transparency in the process with the electoral body (INEC) offering a platform for equal treatment of the parties and contestants, it was the first time in the history of Nigeria that an opposition party wrested power from the ruling party since political independence in 1960.

The elections were keenly and closely fought out by two major parties; the ruling PDP and the opposition party APC, which turned into another equation-the ruling APC and the opposition PDP after the-2015 General Elections. There were controversies, fears, intense campaigns, alliances and re-alliances before the elections. Excessive money that was used by both the ruling PDP and the opposition APC was mostly looted money from the public purse. At last, the elections, contrary to what many Nigerians and international analysts predicted, turned out to be a peaceful transfer of power in a credible and fair process.

The overall conduct of the elections was commendable. INEC succeeded in establishing an improved process of the elections in terms of voter registration, transparent display of voters' list, exhibition of clear rules and regulations for the parties and the contestants, direct involvement of civil societies and international observer groups, and the elections itself which was free of much violence and rigging unlike the previous ones before it.

The 2015 General Elections indicated that the APC emerged with landslide victories in the Presidential, Governorship and National Assembly (Senate and Members of the House of Representatives) elections. This is presented in Tables 1, 2 and 3 
Independent National Electoral Commission and Campaign Financing Monitoring in Nigeria: The 2015

Table 1

2015 Presidential Elections Results in Nigeria

\begin{tabular}{llrc}
\hline Candidate & Party & Votes & Percentage \\
\hline Muhammadu Buhari & APC & $15,424,921$ & $53.96 \%$ \\
Goodluck Ebele Jonathan & PDP & $12,853,162$ & $44.96 \%$ \\
Adebayo Ayeni & APA & 53,537 & $0.19 \%$ \\
Ganiyu Galadima & ACPN & 40,311 & $0.14 \%$ \\
Sam Eke & CPP & 36,300 & $0.13 \%$ \\
Rufus Salau & AD & 30,637 & $0.11 \%$ \\
Mani Ahmad & ADC & 29,665 & $0.10 \%$ \\
Allagoa Chinedu & PPN & 24,475 & $0.09 \%$ \\
Martin Onovo & NCP & 24,455 & $0.09 \%$ \\
Tunde Anifowose Kilani & AA & 22,125 & $0.08 \%$ \\
Chekwas Okorie & UPP & 18,220 & $0.06 \%$ \\
Comfort Sonaiya & KP & 13,037 & $0.05 \%$ \\
Godson Okoye & UDP & 9,208 & $0.03 \%$ \\
Ambrose Albert Owuru & HP & 7,435 & $0.03 \%$ \\
Invalid votes & All Parties & 844,519 & - \\
Total & 14 Parties & $29,432,849$ & $100 \%$ \\
Registered voters & & $67,422,005$ & $100 \%$ \\
\hline
\end{tabular}

Source. INEC 2015.

Table 2

2015 Governorship Elections Results

\begin{tabular}{lll}
\hline Party & Seats & Percentage \\
\hline APC & 19 & $61.29 \%$ \\
PDP & 12 & $38.71 \%$ \\
Total & 31 & $100 \%$ \\
\hline
\end{tabular}

Source: INEC 2015.

The above results indicate that the state Governorship elections took place in 31 of the 36 states in the country as the dates for elections in other states differed. The newly ruling party APC won 19 out of 31 or $61.29 \%$ of the seats while PDP won 12 or $38.71 \%$ of the seats. Seats were also won by APGA Anambra and Osun controlled by APC, the Ondo Labour Party, Edo APC and Bayelsa PDP which made a total of 36 states if added together. In total, APC controlled 21 states (58.33\%), PDP had 13 seats (36.11\%) with APGA and the Labour Party each controlled 1 seat $(2.78 \%)$. 
Table 3

2015 National Assembly Elections Senate

\begin{tabular}{lll}
\hline Party & Seats & Percentage \\
\hline APC & 60 & $55.05 \%$ \\
PDP & 49 & $44.95 \%$ \\
Total & 109 & $100 \%$ \\
\hline
\end{tabular}

Source. INEC 2015

Table 4

House of Representatives

\begin{tabular}{lll}
\hline Party & Seats & Percentage \\
\hline APC & 225 & $62.5 \%$ \\
PDP & 125 & $34.72 \%$ \\
Other Parties & 10 & $2.78 \%$ \\
Total & 360 & $100 \%$ \\
\hline Source. INEC 2015 & &
\end{tabular}

In conclusion, the 2015 General Elections was an improvement from the previous ones and had set the foundation for better political socialisation, voting behaviour and democratic consolidation in Nigeria, and Africa at large. It would go a long way in fostering more improvements in future elections as it is evident that the recent National Assembly's approval of the use of card readers permanently for accreditation and voting will further minimise rigging and other electoral irregularities. It has also influenced many African countries to change their ruling governments in neighbouring Ghana, Gambia, Somalia and other elections like the currently ongoing Liberian and Kenyan elections.

The only annoying issue in the 2015 General Elections was money politics where money was spent crazily above the set limit by the major contending parties. There are speculations of spending of trillions of naira and even revelation of corrupt practices like the diversion of the $\$ 2.1$ billion meant for procurement of weapons to fight Boko Haram insurgency in Northeastern Nigeria which the then National Security Adviser to former President Jonathan shared the money among politicians, party stakeholders, religious clerics, traditional rulers, bureaucrats, electoral body officials, voters and all segments of the country that were related to the election in the country. This is one area that INEC lost control in the elections. Hence it must pay greater attention in addressing it in the 2019 General Elections, otherwise politicians with huge financial muscle will continue to determine the direction of the polity and influence who will contest or not and possibly the winner. 


\section{Theoretical Framework: Structural Functionalism}

This work adopted the theory of structural functionalism to explain the process of elections conducted by INEC between the constitutional powers and the Electoral Act that the Commission had and the actual field activities that the INEC was really doing in practice. The origin, basic assumptions, criticisms and application of the theory within the context of this work are explained below.

\section{Origin of the Theory}

The term structural functionalism originates from Aristotle's study of the ultimate causes in the nature or the actions in relation to their ends or utility. The second phase of the theory was developed by the French philosopher Baron De Montesquieu in the $17^{\text {th }}$ century in his doctrine of separation of powers based on the notion of functions that are best undertaken separate from each other as a means of ensuring stability and security. Functionalism became important when Darwin's Theory of Evolution began to influence the thinking about human behaviour.

In sociological discourse, structural functionalism has root in the works of Durkheim, Parsons (1951) and Merton (1968). The above scholastic ideas became central to the emergence of the theory in modern social sciences. The ideas were later adopted and advanced by political scientists Almond \& Coleman, 1960). ${ }^{34 \mathrm{a}}$ Emile Durkheim in the $19^{\text {th }}$ century believed that societies were made of fragmented blocks that needed to work together for the entire society to function together (Durkheim, 1893). Durkheim (1893) further emphasized that societal bonds must work perfectly otherwise the society would disintegrate. Thus, since the mid$20^{\text {th }}$ century, structural functionalism has become one of the most frequently applied theories in the area of social science particularly sociology and political science which was further advanced by Almond and Coleman (1960).

\section{Basic Assumptions}

Succinctly, structural functionalism has the following basic major assumptions. One of the major assumptions is that society has fragments of structures and their functions work independently and inter-dependently. Thus, there is a clear difference between the ideal function of any organization or societal component and its real function in the society. The second assumption is, there is a relation between a political structure and its function and it may be influenced by certain factors in its function or malfunctioning. The third assumption is, society or the political system should be studied using the real function it is performing and not the proposed or ideal function which may not be applicable in some given conditions. Furthermore, the theory suggests that the political system or the nature of a society determines the structure and functions of organisations and their systems and subsystems. For example, an advanced democratic society might have a better structure that functions accordingly than a backward democratic or developing democracies. 


\section{Criticisms of the Theory}

Critics of structural functionalism view it as a translation of the Anglo-American political norms in methodological terminology. ${ }^{30 c}$ Structural functionalism may be on the decline as a methodological and theoretical approach for the study of politics. However, the theory may not go down easily as it will leave a set of terms that are still used in political jargons. ${ }^{30 \mathrm{~d}}$ Another criticism of structural functionalism is that its categories were too undifferentiated to be of real help in actual research. Also, the theory was criticised on the ground that it harbours ideological slogans of the liberal political scientists, especially American Behaviouralists that portrayed their methodology as scientific and value free. In other words, it was also value laden in nature and approach.

\section{Applicability of the Theory in Research Work}

Four approaches are useful in determining the applicability of structural functionalism. They are process, content, function and form. The processes of the government are elaborately different, discrete and easy to identify in developed countries but in simpler societies the same processes are rarely differentiated and discrete. The content and process are interdependent and derivative.

In essence, taking the environment of our study and the organisation (INEC) as well as its functions it is easy to apply this theory using the methods of its applicability by portraying the fact that Nigeria is categorized, based on this theory, as a simple or developing democracy where the processes of government are not clearly differentiated. An institution such as INEC which supervises the conduct of elections and political parties' activities has no clear distinguished processes between the process and the content. It is evident that the powers and functions of INEC are clearly identified in this work and explained unambiguously, but the problem is the applicability of the process within the content and form of its institutional reality. This is where the theory explains the topic of the study. In other words, there is no clear diversification between the structure and the function in the case of INEC and its role of monitoring campaign finances in the 2015 General Elections in Nigeria because the level of democratic play was still low.

\section{Discussion of Results and Findings}

There are well articulated Constitutional provisions and the 2010 Electoral Act that empowers INEC to monitor and set limits for campaign spending and other activities of INEC and sanction them if they defaulted. Section 225(1-6) and Section 226(1-3) state clearly the powers that INEC had in the Nigerian 1999 Constitution in setting the limit for political parties on what to spend during campaigning, auditing and monitoring their sources of finances, assets and expenditures as well as liabilities and other matters related to it. 
Independent National Electoral Commission and Campaign Financing Monitoring in Nigeria: The 2015

Furthermore, the 2010 Electoral Act provides INEC the powers in Section 91(1-7) to set the limit for maximum campaign spending of various elective offices as follows.

Table 5

Spending Limits of Candidates According to 2010 Electoral Act

\begin{tabular}{ll}
\hline Position & Spending limit \\
\hline Presidential candidate & N1Billion $(\$ 3,183,870.91)$ \\
Governorship candidate & N200Million $(\$ 636,774.18)$ \\
Senatorial candidate & N40Million $(\$ 127,354.84)$ \\
Member of Federal House of Representatives & N20Million $(\$ 63,677.42)$ \\
State House of Assembly Members & N10Million $(\$ 31,838.71)$ \\
L G Chairmanship candidate & N10Million $(\$ 31,838.71)$ \\
L G Councillorship Elections & N1, 000,000 $(\$ 3,183.871)$ \\
\hline
\end{tabular}

Source. Federal Republic of Nigeria, Electoral Act 2010 as amended (the conversion into USD was made by the researcher).

Having realised the intensity of the need to adhere strictly to the above provisions, the Electoral Act further provides INEC with powers to sanction defaulters of the above limit as follows.

Table 6

Sanctions of Violaters of Maximum Campaign Spending in 2010 Electoral Act.

\begin{tabular}{|c|c|}
\hline Position & Sanction \\
\hline Presidential candidate & A fine of $\mathrm{N} 1,000,000=\$ 2,747.060$ ) or imprisonment of 12 months or both. \\
\hline Governorship candidate & A fine of $N 800,000=\$ 2,197.10$ ) or imprisonment of 9 months or both. \\
\hline Senatorial candidate & A fine of $N 600,000=\$ 1,647.93$ ) or imprisonment of six months or both. \\
\hline House of Representatives & A fine of $\mathrm{N} 500,000=\$ 1,373.3$ ) or imprisonment of five months or both. \\
\hline State House of Assembly & A fine of $\mathrm{N} 300,000=\$ 824.042$ ) or 3 months imprisonment or both. \\
\hline Chairman Local Council & A fine of $\mathrm{N} 300,000=\$ 824.042$ ) or 3 months imprisonment or both. \\
\hline Councillor Local Council & A fine of $\mathrm{N} 100,000.00=\$ 274.697$ ) or 1 month imprisonment or both. \\
\hline \multicolumn{2}{|c|}{$\begin{array}{l}\text { Source. Federal Republic of Nigeria, Electoral Act } 2010 \text { as amended (the conversion into USD was made by } \\
\text { the researcher). }\end{array}$} \\
\hline \multicolumn{2}{|c|}{$\begin{array}{l}\text { Apart from the maximum campaign spending limit and the sanction for violators, other } \\
\text { Sections in the Electoral Act } 2010 \text { also empower INEC to monitor finances of political } \\
\text { parties, regulate their assets and liabilities, their sources of income and expenditure in } \\
\text { Sections } 88(1-2), 89(1-4) \text { and } 91(1) \text {. }\end{array}$} \\
\hline
\end{tabular}


However, recent revelations indicated that INEC was not able to monitor properly or rather apply the provisions in terms of limiting the campaign spending to the set limit and its discovery also did not in any way ginger INEC into the action of sanctioning the offenders. It might be for the simple reason that either INEC was not willing to sanction the offenders or it was overpowered by the politicians and the lack of political will from the policy-makers to allow the rules to prevail irrespective of who was affected in the process. This is exactly what structural functionalism explained in terms of the relationship and operation of the structure and function in developing democracies. For example, a study by USAID/UKAID (2015) disclosed that despite the maximum total campaign spending limit of N1Billion (\$3, 183, 870. 91) for a Presidential candidate, the campaign expenses of APC and PDP in media advertisement alone exceeded the maximum spending limit as shown in Table 7.

Table 7

Media Spending of Two Major Political Parties in the 2015 General Elections: APC and PDP

\begin{tabular}{|c|c|c|}
\hline Campaign expenses & PDP Presidential candidate & APC Presidential candidate \\
\hline Campaigns and rallies & $1,280,374,870.00$ & $671,062,200.00$ \\
\hline Expenses on billboards & $473,160,000.00$ & $190,380,000.00$ \\
\hline Electronic media campaign & $532,100,000.00$ & $410,050, \quad 000.00$ \\
\hline Electronic media advert & $3,988,822,125.00$ & $1,064,706,805.00$ \\
\hline Print media campaign & $2,475,228,301.00$ & $579,647,687.00$ \\
\hline TOTAL & $8,749,685,296.00$ & $2,915,846,737.00$ \\
\hline
\end{tabular}

Source. USAID \& UKAID, 2015.

In addition to the above, other revelations disclosed that the extent of campaign spending in the 2015 General Elections in Nigeria had reached trillions of naira by the two major contending parties, APC and PDP, such as in the case of Colonel Sambo Dasuki who diverted \$2.1 billion meant for the purchase of weapons to fight the Boko Haram insurgency. It was channeled into the campaign spending spree of the PDP re-election where security chiefs, party stakeholders, politicians, bureaucrats, religious clerics, traditional rulers, civil societies, INEC officials, voters and all stakeholders involved in the process of the 2015 General Elections were bribed.

Perhaps, INEC failed to monitor effectively the excessive campaign spending of the major political parties because of corruption that some of its officials were involved in corruption. A recent investigation jointly undertaken by EFCC and INEC, revealed that some INEC officials were involved in the bribery scandal. The former Minister of Petroleum, Mrs. Diezani Allison Maduekwe, gave N23 billion $(\$ 63,822,813.191$ million) to some INEC officials, numbering 223 across the 36 States of the Federation and Federal Capital Territory Abuja, to skew the results of the 2015 General Elections in favour of the ruling PDP. The 
case is still under investigation. Although the INEC officials are constitutionally empowered by law to monitor and forward recommendations for the sanction of offenders, the level of monitoring was weak and ineffective.

However, there are some views from the informants consulted in this work that INEC had improved and recorded some success in terms of the monitoring of political parties and politicians' campaign activities including spending as well as the overall conduct of the elections. It was only concerned with the fact that the corrupt practices that had been instituted for a long period of time cannot be undone in just a short period of time; it must be gradual and in this aspect, INEC has been improving and setting some measures to curb the violation of electoral rules such as the introduction of the card reader which gave impetus for the credibility of the elections and drastically minimized the rigging of election results.

Other informants believed that INEC was not really operating as it should and it had failed to monitor the activities and expenditures of parties and politicians because it is a branch of the government which derives its sources of operation and emoluments from the government. Hence, although the ruling APC and the opposition PDP were involved in the violation of the electoral rules in terms of excessive spending, the matter was not investigated by INEC and it was allowed to die a natural death. However, the INEC officials that were involved in the bribery scandal were under investigation and punishment. This simply means the mighty escaped the law comfortably while the weaker ones were trapped.

\section{Conclusion and Recommendation}

The paper concludes that INEC, in its own capacity alone, cannot curb the violation of electoral rules especially in the monitoring of campaign spending of political parties and candidates. This is because although the rules are well elaborated in the Constitution and the Electoral Act which empower INEC to do so, it is failing to do its job because of the dubious nature of the politicians and their powers in subverting regulations to suit their personal interests. The paper also concludes that, INEC has put in more effort and has tried its best in the monitoring process within its capacity but it was limited by corruption from both the ruling class and some of its officials. Also, the paper concludes that, the act of monitoring campaign expenditure should not be in the hands of INEC alone. Other stakeholders need to be involved such as civil societies, anti-graft agencies and the general public. Based on the above conclusion, the paper recommends the following for future action:

1. INEC should be empowered constitutionally and made more independent by making its sources of funds to emerge directly from the consolidated revenue or the Federation account which will minimise its dependency on the executive for statutory allocations and lawmakers for approval. It will enable an independent INEC to discharge its duties freely without any favour; 
2. The maximum spending limit for elective offices stipulated in the 2010 Electoral Act should be revisited upward especially at the top levels considering the nature of Nigerian politics where money played an influential role in the entire process because the current limit going by the inflationary trend in the country is not realizable;

3. Those who are caught in the act of bribery from both the INEC officials and the government officials must be severely punished and the parties should be sanctioned by applying Section 92(1-7) on any violator of the rules;

4. There should be involvement of the anti-graft agencies; EFCC and ICPC, in the screening of candidates and monitoring of campaign spending alongside the INEC for a better collaboration;

5. Civil societies need to expand their work of civic voter education and consultation with INEC to include monitoring and whistle blowing of excessive spending of parties and candidates to the INEC and the public, and

6. There is a need for a strong political will from the policy-makers in allowing INEC the free hand to monitor and sanction offenders without politicising the process.

\section{References}

Abdullahi, S.A. (2015). Youth, political parties and electoral violence in Nigeria. In Mohammed, H. (Ed.). The patterns and dynamics of party politics in Nigeria's fourth republic. Kano: Hallmark Publishing Nigeria LTD.

Ahar, U.C. (2015). Historical dialectics of 2015 presidential election: Implication for sustainable democracy in Nigeria. European Scientific Journal. 11(25), 372-381.

Almond, G.A., \& Coleman, J.S. (1960). The politics of the developing areas. Princeton, N.J.: Princeton University Press.

Ayanda, A, A., \& Odunayo, B.J. (2015). Comparative study of 2011 and 2015 presidential elections in Nigeria. Global Journal of Human Social Sciences: Political Science,15(7), 2-7.

Biezen, I.V. (2003). Financing political parties and election campaigns guidelines. Germany: Council of Europe Publishing.

Bogdan, R.C., \& Biklen, S.K. (2007). Qualitative research for education: An introduction to theories and methods. Boston: Pearson Education.

Braun, C., \& Clarke, P. (2013). Qualitative research method for social science. New Delhi: Pearson Education Inc.

Creswell, J.W. (2014). Research design: Qualitative, quantitative \& mixed method approaches. California: Sage Publication.

Doublet, M.Y.M. (2010). Fighting corruption: Political funding. GRECO's Third Evaluation Round.

Durkheim, E. (1893). The division of labour in society. New York: NY Free Press.

Economic and Financial Crimes Commission 2017.

Electoral Act 2010.

Human Rights Watch. (2007). 
Independent National Electoral Commission and Campaign Financing Monitoring in Nigeria: The 2015 General Elections

Independent National Electoral Commission 2015.

Independent National Electoral Commission 2017.

Innocent, E. O., \& Nkechi, A. (Political financing in Africa: A comparative study for Kenya and Nigeria: Proposal for reform. Mediterranean Journal of Social Sciences MCSER 5(27), 12-26.

International Republic Institute. (2015). Nigeria National Elections (March 28).

Kura, B.Y. (2014). Clientale democracy: Political party funding and candidate selection in Nigeria. African Journal of Political Science and International Relations, 8(5), 124137.

Merton, R.K. (1968). Social theory and social structure. New York: Free Press.

Mohammed, H., \& Aluigba, M.T. (2013). Election rigging and political instability in Nigeria: The case of 2007 General Elections. Journal of Democratic Studies Mambayya House, 3(4), 23-32.

Nigeria's fourth republic. European Journal of Research in Social Sciences, 4(1), 132-142.

Nigerian 1999 Constitution.

Nigerian Legislation 2005. Retrieved from: http://www.commonlii.org/ng/legis/num_act/ ineced571

Olorunmola, A. (2016). Cost of politics in Nigeria. Westminster Foundation for Democracy.

Omilusi, M. (2016). An assessment of political parties and democratic consolidation in Nigeria fourth Republic. European Journal of Research in Social Sciences, 4 (1), 132-142.

Onah, E.I. (2014). Nigeria: A country profile. Journal of International Studies, 10,151-162.

Onah, E.I. (2015). Boko Haram insurgency and the 2015 General Elections in Nigeria. Journal of International Studies. 11, 15-28.

Parsons, T. (1951). The social system. Glencoe: Free Press Publishers.

Sekaran, U., \& Bougie, R. (2013). Research methods for business. India: John Wiley \& Sons.

Sharan, M. P. (2009). Qualitative research method. San Francisco: John Wiley \& Sons.

Smith, M.G. (1966). A structural approach to comparative politics. In Easton, D. (1966) (Ed.), Varieties of political theory Englewood Cliff, N.J.: Prentice Hall.

Sule, B., Azizuddin, M., Sani, M., \& Mat, B. (2017). Political party financing and corruption in Nigeria's fourth republic: The case of 2015 General Elections. Arts and Social Sciences Journal 8(4), 2-8.

Susser, B. (1992). Approaches to the study of politics. New York: Macmillan.

The Centre for Public Policy Alternatives (CPPA). (2015) .2015 Presidential election outcome: Analyses \& implications.

The Observer Book of Scandal 2010.

USAID \& UKAID. (2015) Still above the ceiling. (A Report on Campaign Finance and Use of State Administrative Resources in the 2015 Presidential Election). Centre for Social Justice.

Yagboyaju, D.A. (2011). Nigeria's fourth republic and the challenge of a faltering Democratization. African Studies Quarterly, 12(3), 94-101. 